\title{
Pectinases yeast production using grape skin as carbon source
}

\author{
María Arévalo-Villena ${ }^{1 *}$, Mercedes Fernández ${ }^{2}$, Jesús López ${ }^{2}$, Ana Briones ${ }^{1}$ \\ ${ }^{1}$ Tecnología de Alimentos, Facultad de Ciencia Químicas, Universidad de Castilla la Mancha, Ciudad Real, Spain;
${ }^{2}$ Escuela de Ingeniería Técnica Industrial, Universidad de Castilla la Mancha, Ciudad Real, Spain.
Email: Maria.Arevalo@uclm.es
}

Received 17 January 2011; revised 9 March 2011; accepted 11 March 2011.

\begin{abstract}
Pectinases are used in Enology for some different utilities. Enzymatic preparations from moulds are a mixed of different enzymes with strong and unspecific activities. Some Saccharomyces cerevisiae produce pectinases which can be used instead of commercial preparations. The objectives of this work were to study the enzyme secretion by one Saccharomyces cerevisiae (CECT 11783) for growing on grape skin (industry oenological by-product) as carbon source. Preliminary experiments showed that the strain produced pectinases for growing on grape skin without any other carbon source. Statistical treatment (factorial design $2^{5}$ ) was applied to evaluate the influences of related factors (agitation, temperature, presence of peptone and detergent in the medium and time of growth) Variables with the most significant interactions for pectinase production were agitation and nitrogen source concentration. Response surface methodology showed that a first order model was not adequate for results. Nevertheless, the built of a second order model offered a polynomial equation which surface predicted a maximum of activity (52.68 enzymatic units) for specific values of the studied variables (147.8 rpm of agitation and $15.9 \mathrm{~g}$ of peptone/L culture medium).
\end{abstract}

Keywords: Pectinase Enzyme from Yeast; Enology; Grape Skin; Statistical Treatment; Response Surface Methodology

\section{INTRODUCTION}

Pectinolytic enzymes are found mainly in moulds and bacteria, but they also occur in some yeasts [1-3]. Given the role played by yeasts, especially of the genus $\mathrm{Sac}$ charomyces, in fermented products, further research into their pectinolytic enzymes would be useful for two purposes: one, so that yeast can be used to synthesize then purify the enzymes for addition to fruit juices as clarifi- cation and extraction enhancers; and two, in the case of fermented products, so that the enzyme can be produced by the yeast as part of the process rather than having to be added to the medium.

Most commercial pectinase preparations used in the food industry are derived from Aspergillus niger, a GRAS microorganism producing large quantities of these enzymes. However, this mould secretes other enzymes which may trigger collateral reactions, such as the release of volatile phenols less desirable for the production of wine or fruit juices, for instance arabinofuranosidase, which can cause turbidity [4].

Pectinases are used in winemaking to enhance must extraction by degrading structural polysaccharides which interfere with the extraction process [5], thus increasing the release of colour and aroma compounds in musts both before and during fermentation. At the same time, the addition of pectinases improves maceration, clarification and filtration during the winemaking process [6-8].

Pectinolytic enzymes derived from Saccharomyces cerevisiae would provide a useful alternative to mouldderived pectinases, since a genuine product can only be obtained from yeasts.

Certain strains of $S$. cerevisiae have been found to break down polygalacturonic acid, which could be important for the fermentation of plant-derived substrates $[1,9]$.

It has been demonstrated that when the enzyme extract from Saccharomyces bayanus is added to fresh must, the effects on turbidity are the same as when a commercial enzyme preparation is added [10].

A study reported that when $\mathrm{PG}+$ strains of $S$. cerevisiae were used in winemaking, in some cases the filtration time was reduced by half without any appreciable changes in viscosity [11]. Moreover, a transformed strain with good winemaking qualities has more recently been engineered using the $P G U 1$ gene from another strain, transcriptionally bonded to the $P G K 1$ gene promoter, in order to enhance its expression during growth [12]. 
In some countries, current legislation prohibits the use of genetically-modified organisms, though not of GMOderived enzymes, in winemaking. The first step towards achieving this goal is to develop appropriate enzymeproduction technology.

Spanish grape-skin production, as a by-product of the winemaking process, is estimated at around 750000 tonnes per year. At present, it is used mostly as animal feed. Polygalacturonase activity in grape musts has been shown to increase markedly one day after the addition of yeast, whereas no enzyme activity was detected throughout fermentation in must made from juice alone [13].

The incorporation of grape skin in the formulation of culture media for use in industrial enzyme production would bring both economic and environmental benefits for winemaking areas, by enabling commercial exploitation of this by-product. The composition of grape skin may well enhance yeast growth as well as inducing pectinase synthesis.

The aim of this research was to optimize the culture medium using grape skin as substrate for the growth and synthesis of pectinases derived from a geneticallymodified yeast strain.

Statistical optimization was preferred because it enabled evaluation of interactions between parameters and involved a specific experimental design [14,15].

\section{MATERIAL AND METHODS}

A genetically-modified Saccharomyces cerevisiae strain (CECT 11783) (12) was used, containing the gene $P G U 1$ from a spontaneous winemaking yeast, which conferred the ability to hydrolyze polygalacturonic acid and therefore pectins.

For all assays, cells were precultured in YPD broth to enable inoculation of a final population of $10^{7}$ cells $/ \mathrm{mL}$ onto each tested growth medium.

\subsection{Enzyme Method for Determining Pectinolytic Activity}

Pectinolytic activity was evaluated by quantifying the amount of galacturonic acid released from apple pectin (Fluka) using the DNSA (dinitrosalicylic acid) reaction. The method was optimized by adjusting reagent concentrations and incubation times. A commercial pectinase was used as positive control, and a commercial Saccharomyces strain (UCLM S325) not possessing pectinolytic activity served as negative control.

Results were plotted on a galacturonic-acid calibration curve covering the appropriate range of concentrations.

\subsection{Preliminary Tests. Relationship between Yeast Growth and Pectinase Production}

\subsubsection{First Experiment}

A number of prior experiments were performed to con- firm the ability of yeast to grow and to synthesize polygalacturonase in the presence of grape skin. The yeast was grown on the following media:

$7 \mathrm{~g} / \mathrm{L}$ grape skin

$7 \mathrm{~g} / \mathrm{L}$ grape skin $+5 \mathrm{~g} / \mathrm{L}$ glucose

$7 \mathrm{~g} / \mathrm{L}$ grape skin $+10 \mathrm{~g} / \mathrm{L}$ peptone

$7 \mathrm{~g} / \mathrm{L}$ grape skin $+5 \mathrm{~g} / \mathrm{L}$ glucose $+10 \mathrm{~g} / \mathrm{L}$ peptone

A set of $100-\mathrm{mL}$ flasks containing $20 \mathrm{~mL}$ of each medium were inoculated and incubated at $28^{\circ} \mathrm{C}$ in a thermostatically-controlled water bath shaker (150 rpm). Polygalacturonase activity was measured at 24, 46 and 96 hours of yeast growth.

All assays were performed in triplicate, and results were expressed in enzyme units (i.e. the amount of enzyme required to liberate 10 ug of galacturonic acid from apple pectin in the conditions outlined above).

\subsubsection{Second Experiment}

In view of the results obtained, a second experiment was performed to ascertain whether grape skin and/or glucose concentrations significantly influenced enzyme synthesis. For this purpose, peptone concentration and growth time (determinant variables) were fixed at $10 \mathrm{~g} / \mathrm{L}$ and $24 \mathrm{~h}$, respectively. Yeast was grown in a refrigerated orbital shaker which was used until the end of the work. The new media formulations were as follows:

$0 \mathrm{~g} / \mathrm{L}$ grape skin $+5 \mathrm{~g} / \mathrm{L}$ glucose $+10 \mathrm{~g} / \mathrm{L}$ peptone

$7 \mathrm{~g} / \mathrm{L}$ grape skin $+5 \mathrm{~g} / \mathrm{L}$ glucose $+10 \mathrm{~g} / \mathrm{L}$ peptone

$21 \mathrm{~g} / \mathrm{L}$ grape skin $+5 \mathrm{~g} / \mathrm{L}$ glucose $+10 \mathrm{~g} / \mathrm{L}$ peptone

$7 \mathrm{~g} / \mathrm{L}$ grape skin $+10 \mathrm{~g} / \mathrm{L}$ peptone

$21 \mathrm{~g} / \mathrm{L}$ grape skin $+10 \mathrm{~g} / \mathrm{L}$ peptone

\subsection{Optimization of the Culture Medium for Pectinase Production. Statistical Analysis}

In the light of the preliminary study results, the grape skin concentration was set at $21 \mathrm{~g} / \mathrm{L}$ and glucose was omitted from the culture broth; a study was therefore made of other variables potentially influencing enzyme synthesis.

A two-stage statistical analysis was performed: the first stage identified significant factors, while in the second stage response surface methodology (RSM) was used to maximize enzyme activity.

\subsubsection{First Stage}

The conditioning variables studied were: agitation (shaking speed), temperature, presence of detergent (Tween 80), cell harvest time and presence of a nitrogen source (peptone); these variables were selected in view of their marked influence on enzyme synthesis by yeasts (16).

Each variable was studied at two levels, so that the combination of five variables (factorial design $2^{5}$ with two replications) gave a total of 64 runs.

The experimental design used is shown in Table 1. 
Table 1. Experimental design for identification of significant factors in enzyme production. (Agitation, temperature, presence of detergent (Tween 80), cell harvest time and presence of a nitrogen source (peptone)).

\begin{tabular}{|c|c|c|c|c|c|c|}
\hline Experiment A & Experiment B & Experiment C & Experiment D & Tween 80 & Time (h) & Peptone \\
\hline A1 & B1 & C1 & D1 & - & 12 & - \\
\hline A2 & B2 & $\mathrm{C} 2$ & D2 & + & 12 & - \\
\hline A3 & B5 & C5 & D5 & + & 48 & - \\
\hline A4 & B6 & C6 & D6 & + & 12 & + \\
\hline A5 & B3 & C3 & D3 & - & 48 & - \\
\hline A6 & B4 & $\mathrm{C} 4$ & D4 & - & 12 & + \\
\hline A7 & B8 & C8 & D8 & + & 48 & + \\
\hline A8 & B7 & C7 & D7 & - & 48 & + \\
\hline
\end{tabular}

Experiment A: Agitation $50 \mathrm{rpm}$, temperature $18^{\circ} \mathrm{C}$

Experiment B: Agitation $150 \mathrm{rpm}$, temperature $18^{\circ} \mathrm{C}$

Experiment C: Agitation $50 \mathrm{rpm}$, temperature $28^{\circ} \mathrm{C}$

Experiment D: Agitation $150 \mathrm{rpm}$, temperature $28^{\circ} \mathrm{C}$

The four possible combinations of shaking speed (50 and $150 \mathrm{rpm})$ and temperature (18 and $28^{\circ} \mathrm{C}$ ) were fixed; 8 experiments were performed in duplicate for each combination to quantify the amount of enzyme produced, expressed as enzyme units.

The replicated $2^{5}$ factorial model was constructed using the SPSS statistical software package. The univariate GLM procedure was used to examine the magnitude and direction of factor effects.

The design model was based on the equation:

$$
\begin{aligned}
y_{i j k l m h} & =\mu+\alpha_{i}+\beta_{j}+\gamma_{k}+\delta_{l}+\xi_{m}+(\alpha \beta)_{i j}+(\alpha \gamma)_{i k} \\
& +(\alpha \delta)_{i l}+\cdots+(\delta \xi)_{l m}++(\alpha \beta \gamma)_{i j k}+\cdots+(\gamma \delta \xi)_{k l m} \\
& +(\alpha \beta \gamma \delta) i j k l+\cdots+(\beta \gamma \delta \xi)_{j k l m}+(\alpha \beta \gamma \delta \xi) i j k l m \\
& +e_{i j k l m h}
\end{aligned}
$$

where $i, j, k, l, m$ took the values 1 and 2 , and $\mathrm{h}$ varied between 1 and the number of replicates (in this case, 2).

In the first instance, a full factorial model was constructed using the five main factors, ten second-order interactions and ten third-order interactions. Factor effects and significant interactions were then estimated by the UNIANOVA procedure using pairwise comparisons and profile plots.

\subsubsection{Second Stage}

The results from the first stage indicated that neither detergent (Tween 80) nor cell harvest time were significant variables, and that the optimum temperature was $28^{\circ} \mathrm{C}$. For technical and economic reasons, therefore, the following variables were fixed: temperature $\left(28^{\circ} \mathrm{C}\right)$, grape skin concentration $(21 \mathrm{~g} / \mathrm{L})$ and cell harvest time (24 h); thus only shaking speed and peptone concentration were studied at the second stage.

First, a linear approach to optimal conditions was carried out using first-order strategies and a $2^{2}$ factorial design with three replications of the centre-point (values of the central conditions of each assay): agitation $=150$ rpm, peptone concentration $=10 \mathrm{~g} / \mathrm{L}$. Model suitability was assessed by analysing fit and curvature, and estimating experimental error. Shaking speed was set at 150 rpm, and peptone concentrations were tested at $2 \mathrm{~g} / \mathrm{L}$ intervals up to $20 \mathrm{~g} / \mathrm{L}$, giving a total of 7 assays.

Since results were not determinant (data not shown), the test was repeated with a new centre-point (shaking speed $=150 \mathrm{rpm}$, peptone $=14 \mathrm{~g} / \mathrm{L}$ ), which involved performing a further 7 experiments.

\section{RESULTS AND DISCUSSION}

\subsection{Enzyme Method for Determining Pectinolytic Activity}

The enzyme reaction providing the best results was a mixture of $500 \mu \mathrm{L}$ of supernatant (enzyme) with $500 \mu \mathrm{L}$ of $0.25 \%$ apple pectin, incubated for 30 minutes at $37^{\circ} \mathrm{C}$. Once the reaction was complete, $500 \mu \mathrm{L}$ of the mixture was reacted with $500 \mu \mathrm{L}$ of DNSA, and incubated for 10 minutes at $100^{\circ} \mathrm{C}$.

The cooled reaction mixture was diluted with $1.2 \mathrm{~mL}$ of water, and data were plotted on a galacturonic acid calibration curve ranging from 0.1 to $1 \mathrm{mg} / \mathrm{mL}$.

\subsection{Preliminary Tests. Relationship between Yeast Growth and Pectinase Production}

\subsubsection{First Experiment}

Extracellular pectinase activity at various harvest times using different growth media is shown in Figure 1. Activity was influenced by medium composition and the presence of a nitrogen source (peptone) stimulating pectinase synthesis (growth media $\mathrm{C}$ and $\mathrm{D}$ ).

One-way analysis of variance (ANOVA, 95\% CI) revealed that enzyme production differed significantly in all tested media at $46 \mathrm{~h}$. Maximum enzyme production was observed with the grape skin + glucose + peptone 


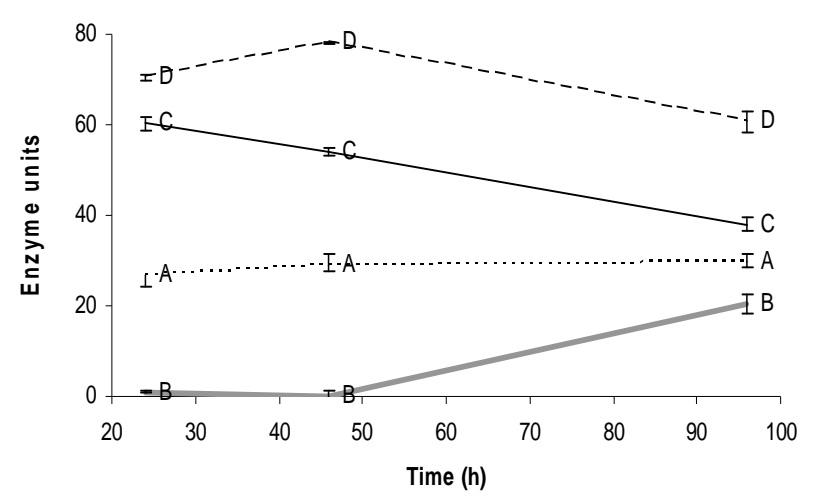

Figure 1. Evolution of pectinolitic activity in some culture media at different harvest time. A. $7 \mathrm{~g} / \mathrm{L}$ skin; B. $7 \mathrm{~g} / \mathrm{L}$ skin +5 g/L glucose; C. 7 g/L skin +10 g/L peptone; D. 7 g/L skin +5 $\mathrm{g} / \mathrm{L}$ glucose $+10 \mathrm{~g} / \mathrm{L}$ peptone.

combination (medium D) at 46 hours; the maximum value of $78.25 \pm 0.2$ enzyme units was significantly higher than that obtained with all the other combinations. This higlights the importance of peptone for yeast growth and thus for enzyme synthesis; indeed, the second-highest value $(60.3 \pm 1.4)$ was obtained with peptone-containing medium $\mathrm{C}$.

The influence of cell harvest time on enzyme production in each medium varied as a function of medium composition: variations in harvest time had no significant effect on production in the medium containing only grape skin, but prompted significant differences in the other three media. For the grape skin + glucose + peptone combination (medium D), enzyme production peaked at $46 \mathrm{~h}$. When glucose was removed (medium C), production peaked earlier (24 h); however, the difference between the two harvest times, though significant, was not marked. Finally, in the medium containing glucose but not peptone (medium B), enzyme synthesis was significantly inhibited in the early stages; although some activity was detected later, values never approached those obtained using a nitrogen source.

\subsubsection{Second Experiment}

Yeast was grown in media I, II, III, IV and V (detailed under Material and Methods) to determine the influence of glucose and/or grape skin on pectinolytic activity. No significant differences (95\% CI) in enzyme production were noted, values of around 40 enzyme units being recorded in all cases (Table 2). The positive effect of glucose in medium II was matched by the increased grape-skin concentration in medium $\mathrm{V}$.

In the absence of statistically-significant differences, the decision to use a peptone-containing medium in which the carbon source (glucose) was replaced by an increased grape skin concentration (21 g/L) was prompted by the fact that this medium proved cheaper and also made profitable use of a winemaking by-product.

\subsection{Optimization of the Culture Medium for Pectinase Production. Statistical Analysis}

\subsubsection{First Stage}

Enzyme activity for the 64 runs detailed under Material and Methods is shown in Table 3. Enzyme production was significantly affected by all tested variables except presence of detergent. In experiment A (agitation $50 \mathrm{rpm}$, temperature $18^{\circ} \mathrm{C}$ ), activity was negligible or nonexistent due to minimal yeast growth, attributable to stress conditions.

With these results, statistical analysis was repeated,

Table 2. Production of pectinolitic enzyme in media with different skin and glucose concentration.

\begin{tabular}{llc}
\hline \multicolumn{1}{c}{ Culture medium } & Enzyme units \\
\hline I. & 0 g/L skin +5 g/L glucose +10 g/L peptone & $43.3 \pm 3.1$ \\
II. $\quad 7$ g/L skin +5 g/L glucose +10 g/L peptone & $48.5 \pm 2.2$ \\
III. $\quad 21 \mathrm{~g} / \mathrm{L}$ skin +5 g/L glucose $+10 \mathrm{~g} / \mathrm{L}$ peptone & $39.8 \pm 7.9$ \\
IV. $\quad 7$ g/L skin + 10 g/L peptone & $42.4 \pm 4.5$ \\
V. $\quad 21$ g/L skin + 10 g/L peptone & $47.5 \pm 1.5$ \\
\hline
\end{tabular}

Table 3. Pectinolitic activity obtained by Table 1 design.

\begin{tabular}{ccccc}
\hline Experiment A $\left(\mathbf{5 0} \mathbf{~ r p m} / \mathbf{1 8}^{\mathbf{0}} \mathbf{C}\right)$ & Tween $\mathbf{8 0}$ & Time $\mathbf{( h )}$ & Peptone & Enzyme units \\
\hline 1 & - & 12 & - & $3.2 \pm 0.6$ \\
2 & + & 12 & - & $3.6 \pm 2.6$ \\
3 & + & 48 & + & $\mathrm{Nd}^{*}$ \\
4 & + & 12 & - & + \\
5 & - & 48 & + & \\
6 & - & 48 & + & + \\
7 & + & 48 &
\end{tabular}




\begin{tabular}{ccccc}
\hline Experiment B $\left.\mathbf{( 1 5 0} \mathbf{~ r p m} / \mathbf{1 8}^{\circ} \mathbf{C}\right)$ & Tween $\mathbf{8 0}$ & Time $\mathbf{( h )}$ & Peptone & Enzyme units \\
\hline 1 & - & 12 & - & $20.3 \pm 0.5$ \\
2 & + & 12 & - & $26.7 \pm 8.8$ \\
3 & - & 48 & - & $18.3 \pm 0.9$ \\
4 & - & 12 & + & $21.6 \pm 0.5$ \\
5 & + & 48 & - & $30.8 \pm 0.5$ \\
6 & + & 12 & + & $23.6 \pm 6.7$ \\
7 & - & 48 & + & $25.1 \pm 1.7$ \\
8 & + & 48 & + & $25.6 \pm 1.2$ \\
\hline
\end{tabular}

\begin{tabular}{ccccc}
\hline Experiment $\mathbf{C}\left(\mathbf{5 0} \mathbf{~ r p m} / \mathbf{2 8}^{\mathbf{0}} \mathbf{C}\right)$ & Tween $\mathbf{8 0}$ & Time $\mathbf{( h )}$ & Peptone & Enzyme units \\
\hline 1 & - & 12 & - & $15.7 \pm 0.3$ \\
2 & + & 12 & - & $15.0 \pm 3.9$ \\
3 & - & 48 & - & $12.7 \pm 0.2$ \\
4 & - & 12 & + & $34.6 \pm 1.3$ \\
5 & + & 48 & - & $13.6 \pm 0.2$ \\
6 & + & 12 & + & $37.0 \pm 0.8$ \\
7 & - & 48 & + & $35.1 \pm 1.6$ \\
8 & + & 48 & + & $35.3 \pm 0.9$ \\
\hline
\end{tabular}

\begin{tabular}{ccccc}
\hline Experiment D $\left.\mathbf{( 1 5 0 ~} \mathbf{~ r p m} / \mathbf{2 8}^{\mathbf{}} \mathbf{C}\right)$ & Tween $\mathbf{8 0}$ & Time $\mathbf{( h )}$ & Peptona & Enzyme units \\
\hline 1 & - & 12 & - & $23,8 \pm 0,2$ \\
2 & + & 12 & - & $27,8 \pm 1,1$ \\
3 & - & 48 & - & $11,3 \pm 0,5$ \\
4 & - & 12 & + & $41,1 \pm 0,2$ \\
5 & + & 48 & - & $12,4 \pm 0,4$ \\
6 & + & 12 & + & $44,1 \pm 0,2$ \\
7 & - & 48 & + & $25,5 \pm 1,8$ \\
8 & + & 48 & + & $30,9 \pm 0,6$ \\
\hline
\end{tabular}

* Nd. No detected

retaining those main variables and second-order interactions significantly influencing polygalacturonase synthesis. The shaking speed*temperature combination was not significant, and was therefore omitted from the statistical analysis. The time factor, though also non-significant, was retained since it was contained in two significant interactions. This gave rise to a custom model 2:

$$
\begin{aligned}
\text { Activity }= & \mu+\alpha+\beta+\gamma+\delta+(\alpha \gamma) \\
& +(\alpha \delta)+(\beta \gamma)+(\beta \delta)+\text { error }
\end{aligned}
$$

where $\mu$ was the overall mean of runs, $\alpha, \beta, \gamma$, and $\delta$ the parameters due to the effects of agitation, temperature, time and presence of peptone, respectively; and $(\alpha \gamma, \alpha \delta$, $\beta \gamma$ and $\beta \delta$ ) the parameters corresponding to the respective interactions.

Significant effect estimations showed that an agitation of $150 \mathrm{rpm}$ increased enzyme activity by 4.76 units, i.e. an increase of $25.2 \%$ compared to $50 \mathrm{rpm}$. Similarly, enzyme production at $28^{\circ} \mathrm{C}$ was 5.76 units (33\%) higher than at $18^{\circ} \mathrm{C}$. Production in peptone-containing media was 11.49 units (65.5\%) higher than in peptone-free media.

Significant interaction estimations were obtained using profile plots, and the results were used as the basis for the next experiment. An example of a profile plot is provided in Figure 2. No interaction was recorded between presence of peptone and either agitation (B) or temperature (D); by contrast, both these latter variables interacted with time (A and C, respectively).

To summarize, the highest enzyme activity was found at $28^{\circ} \mathrm{C}, 150 \mathrm{rpm}$ and in media containing peptone as nitrogen source.

\subsubsection{Second Stage}

On the basis of these results, temperature was fixed at $28^{\circ} \mathrm{C}$, harvest time at $24 \mathrm{~h}$ and grape skin concentration at $21 \mathrm{~g} / \mathrm{L}$. The results indicated that the response func- 


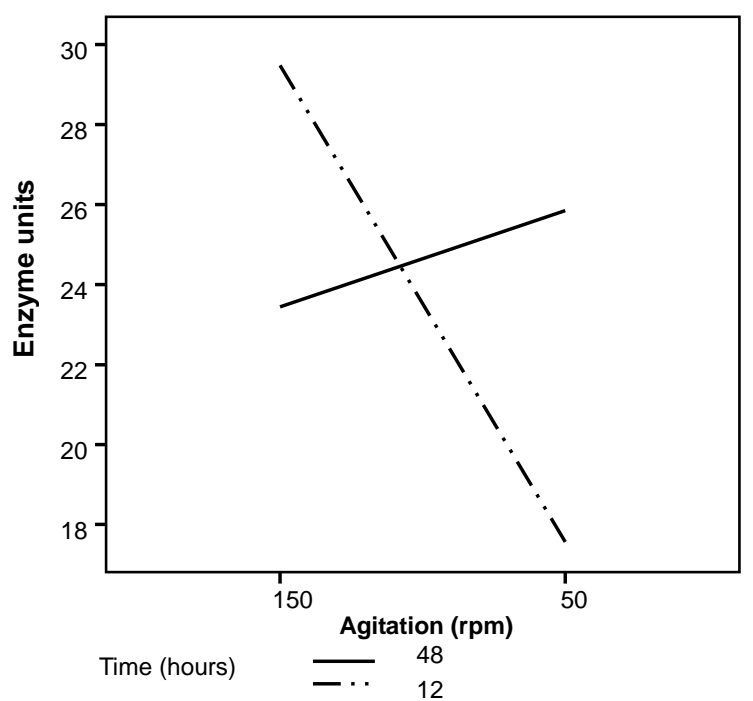

(a)

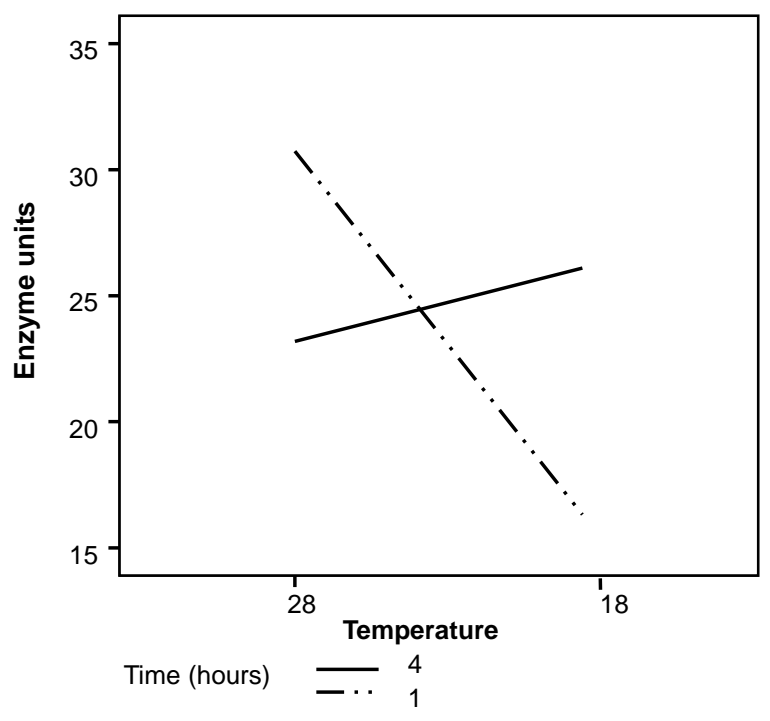

(c)

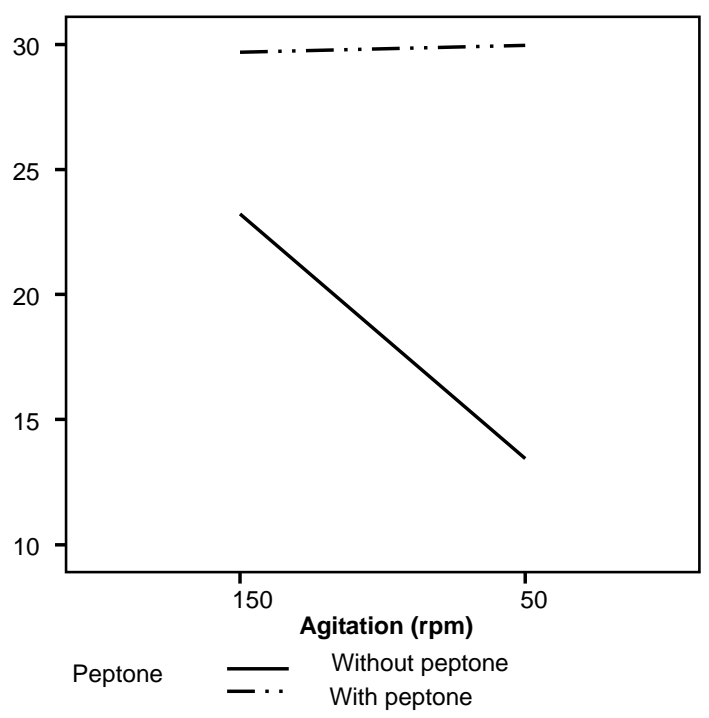

(b)

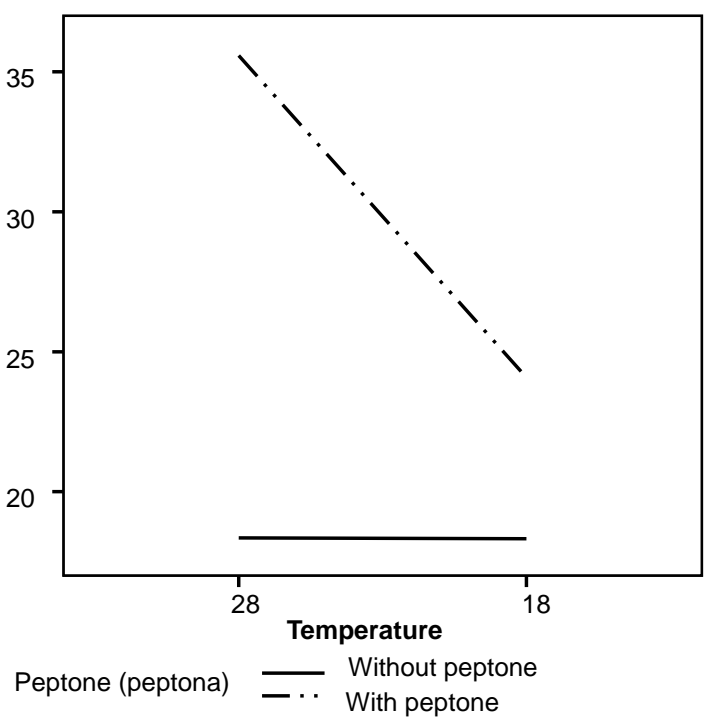

(d)

Figure 2. Profile graphics of some interactions between studied variables on pectinolitic enzymes formation. (a) Agitation and time interaction; (b) Agitation and peptone presence interaction; (c) Temperature and time interaction; (d) Temperature and peptone presence interaction.

tion curve was not suitable for the first-order model. A second-order model was therefore constructed, involving a central composite design containing a $2^{2}$ factorial design with three centre points and a star design with a further three centre points. The polynomial equation representing the second-order model used to account for enzyme activity was:

$$
\begin{aligned}
Y^{\prime}= & 51^{\prime} 987-0^{\prime} 052 x_{1}+2^{\prime} 107 x_{2} \\
& -3^{\prime} 557 x_{1}^{2}-1^{\prime} 645 x_{2}^{2}-0^{\prime} 71 x_{1} x_{2}
\end{aligned}
$$

The fitted response surface and contour plot for pectinase production are shown in Figure 3(a) and 3(b), respectively. The three-dimensional umbrella-shaped curve represented the main effect of the tested variables (presence of peptone and agitation) and their interaction with maximum pectinase production by Saccharomyces cerevisia strain CECT 11783. As Figure 3 shows, a maximum point was located at roughly $16 \mathrm{~g} / \mathrm{L}$ of peptone and around $150 \mathrm{rpm}$ of agitation. According to the model, $\left(150+30 \mathrm{X}_{1}\right)$ and $\left(14+3 \mathrm{X}_{2}\right)$, predicted maximum 

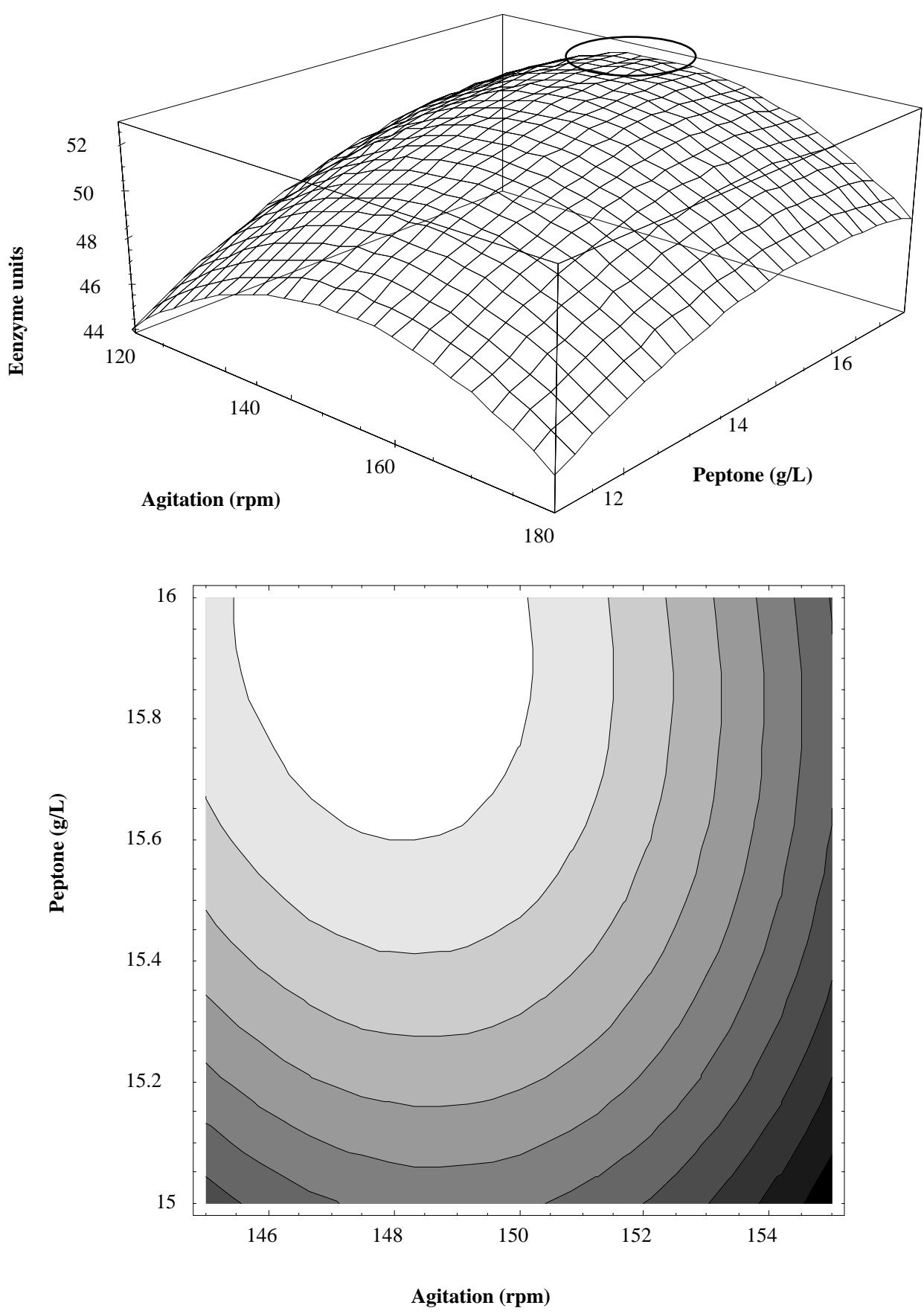

Figure 3. Response surface (a) and contour plot for second order model in nature variables (agitation and peptone concentration) for pectinases production.

pectinase production using grape skin was 52.68 enzyme units, using an agitation of $147.8 \mathrm{rpm}$ and a grape skin concentration of $15.9 \mathrm{~g} / \mathrm{L}$.

\section{CONCLUSIONS}

The present study offers the possibility of obtaining pectinases from yeast using a byproduct from the same industry: grape skin. The statistical studies guarantied the maximum enzyme production under specific culture conditions: growth of CECT 11783 using $16 \mathrm{~g} / \mathrm{L}$ of peptone, $21 \mathrm{~g} / \mathrm{L}$ of dried grape skin as carbon source and inductor of the pectinases synthesis with an agitation of $150 \mathrm{rpm}$. These concentrations could be adjusted getting a compromised between quantity of produced enzyme 
and economic factors.

\section{ACKNOWLEDGEMENTS}

This study was funded by INIA project (RM 2007 00004-00-00).

\section{REFERENCES}

[1] Fernández-González, M., Ubeda, J.F., Vasudevan, T.G., Otero and Briones, R.A. (2004) Evaluation of polygalacturonase activity in Saccharomyces cerevisiae wine strains. FEMS Microbiology Letters, 237, 261-266.

[2] Jayani, R. Singh, Saxena, S. and Gupta, R. (2005) Microbial pectinolitic enzymes: A review. Proccess Biochemistry, 40, 2931-2944. doi:10.1016/j.procbio.2005.03.026

[3] Oliveira, K.F., Malavolta, L., Souza, C.S., Vicente, E.J. and Laluce, C. (2006) Pectinoytic activity secreted by yeasts isolated from fermented citrus molasses. Journal of Applied Microbiology, 100, 633-640. doi:10.1111/j.1365-2672.2006.02823.x

[4] Whitaker, J.R. (1990) Microbial pectinolitic enzymes. In: Fogarty, W.M. and Kelly, C.T., Eds., Microbial Enzymes and Biotechnology. 2nd Edition, Elsevier Science Ltd., London, 133-176.

[5] Roldán, A., Palacios, V., Peñatez, X., Benitez, T. and Pérez, L. (2006) Use of Trichoderma enzymatic extracts on vinification of Palomino fino grapes in the Sherry region. Journal of Food Engineering, 75, 375-382. doi:10.1016/j.jfoodeng.2005.03.065

[6] Villetaz, J.C. (1990) Les colloides colmatant et la filtration des vins. Reveu Francaise d'oenologie, 122, 59-63

[7] Villetaz, J.C. (1996) Utilisitain les enzymes en oenologie pour l'extraction de la couleur et por l'extration et la revelation des aromes. Bulletin de l'OIV, 787, 843-869.

[8] Servili, M., Begliomini, A.L. and Montedor, G. (1992) Utilization of a yeast pectinase in olive oil extraction and red wine making processes. Journal of Science and Food Agriculture, 58, 253-260. doi:10.1002/jsfa.2740580214

[9] McKay, A.M. (1990) Degradation of polygalacturonic acid by Saccharomyces cerevisiae. Letter in Applied Microbiology, 11, 41-44.

[10] Gainvors, A., Frézier, V., Lemarasquier, H., Lequart, C., Aigle, M. and Belarbi, A. (1994) Detection of polygalacturonase, pectin-lyase and pectin-esterase activities in a Saccharomyces cerevisiae strain. Yeast, 10, 1311-1319. doi:10.1002/yea.320101008

[11] Blanco, P., Sieiro, C., Díaz, A., Reboredo, M. and Villa, T.G. (1997) Grape juice biodegradation by polygalacturonases from Saccharomyces cerevisiae. International Biodeterioration and Biodegradation, 40, 115-118. doi:10.1016/S0964-8305(97)00055-3

[12] Fernández-González, M., Úbeda, J.F., Cordero-Otero, R.R., Thanvanthri Gururajan, V. and Briones, A.I. (2005) Engineering of an oenological Saccharomyces cerevisiae strain with pectinolytic activity and its effect on wine. International Journal of Food Microbiology, 102, 173183. doi:10.1016/j.ijfoodmicro.2004.12.012

[13] Takayanagi, T., Uchibori, T. and Yokotsuka, K. (2001) Characteristics of yeast polygalacturonases induced during fermentation on grape skins. American Journal of Enology and Viticulture, 52, 41-44.

[14] Fernández Valdivia, D.G., Espinola Lozano, F. and Moya Vilar, M. (2008) Influencia de diferentes coadyuvantes tecnológicos en la calidad y rendimiento del aceite de oliva virgen utilizando la metodología de superficies de respuesta. Grasas y Aceites, 59, 39-44.

[15] Vasconcelos, A.F., Barbosa, A., Dekker, R., Scarminio, I. and Rezende, M.I. (2000) Optimization of lacase production by Botriosphaeria sp., in the presence of veratryl alcohol by the response-surface method. Process in Biochemistry, 35, 1131-1138. doi:10.1016/S0032-9592(00)00149-7 